\title{
THE RELATIONSHIP BETWEEN ATTITUDES AND UTILIZATION OF MCH HANDBOOKS WITH BASIC IMMUNIZATION COMPLETENESS DURING THE COVID- 19 PANDEMIC IN SUKOHARJO
}

\author{
Soqifah Trias Parawansya ${ }^{1}$, Woro Setia Ningtyas ${ }^{2}$, Dwiyanti Puspitasari ${ }^{3}$ \\ ${ }^{1}$ Department of Midwifery Education, Faculty of Medicine University Airlangga 60132, Surabaya, East Java, Indonesia \\ ${ }^{2}$ Department of Midwifery Education, Faculty of Medicine University Airlangga 60132, Surabaya, East Java, Indonesia \\ ${ }^{3}$ Department of Pediatric, Faculty of Medicine University Airlangga 60132, Surabaya, East Java, Indonesia \\ Corresponding Author : woro.setia @ fk.unair.ac.id
}

\begin{abstract}
Background The COVID-19 pandemic has caused the worst public health crisis and has impacted global social norms, and disrupted health services, one of which impacts basic immunization. Basic immunization is one of the services at the posyandu, a quick survey conducted in June showed that $75 \%$ of posyandu in Indonesia did not provide services due to the COVID-19 pandemic. During this COVID-19 pandemic, parents are worried about their child's transmission of COVID-19 if they meet with other people, and must carry out basic immunizations at health service places due to the absence of Posyandu. Then how about the completeness of basic immunization during a pandemic? Is the attitude and use of the $\mathrm{MCH}$ handbook related to the completeness of basic immunization during the COVID-19 pandemic. Method Type of quantitative research with a cross-sectional design, using secondary data photos on the basic immunization record sheet, and primary data in the form of answers to questionnaires by respondents. The sampling technique used quota sampling until 100 samples were met. Inclusion criteria were mothers who had children aged 0-20 months, had an MCH handbook, lived in the Sukoharjo area, were not illiterate, and were willing to be research respondents. Result The relationship between attitude and completeness of basic immunization has $\mathrm{p}$-value $=$ 0.001 ( $\mathrm{p}<0.05$ ). The relationship between the use of $\mathrm{MCH}$ handbooks and the completeness of basic immunization has a value of $\mathrm{p}=0.000(\mathrm{p}<0.05)$. Conclusion The attitude factor and the use of MCH books by respondents had a significant relationship with the completeness of basic immunization.
\end{abstract}

Keywords: Covid-19, Attitude, MCH, Basic Immunization

\section{Introduction}

A novel coronavirus disease (2019-nCoV) that caused an acute respiratory syndrome epidemic was first reported in Wuhan, China, in December 2019 (Zhou et al., 2020). The disease caused by the new coronavirus is then referred to as Corona-virus disease-2019 (COVID-19). The current COVID-19 pandemic is causing the worst public health crisis. Based on central COVID-19 data on 9 May 2021, in Indonesia, more than 1.7 million confirmed positive cases of COVID-19, and more than 46 thousand cases of death due to COVID-19 (Jayani, 2021). And in the Sukoharjo area, on May 15, 2021, COVID-19 reached 5,906 positive confirmed cases, and 418 of them died (JOGJA, 2021). The COVID-19 pandemic has impacted global social norms and disrupted health services. This will impact public health, one of which impacts basic immunization.

The role of immunization to prevent illness, disability, and death from dangerous diseases has been recorded in world history. Diseases that can be prevented by immunization (PD3I) include Smallpox, 
Tuberculosis, Polio, Diphtheria, Measles, Rubella, Tetanus, Meningitis, Pneumonia, and Hepatitis B which cause liver cancer (Kementerian Kesehatan Republik Indonesia, 2020). One of the efforts for a sustainable reduction in morbidity and mortality from preventable diseases throughout an individual's life cycle is immunization (Scobie et al., 2020). If the morbidity and mortality from disease decrease, it will have significant health, economic and social impact (Privor-Dumm et al., 2020). It is estimated that 1.7 million deaths in children or 5\% of children under five in Indonesia are due to PD3I. Illness and mortality rates of communicable and non-communicable diseases in Central Java Province are still high (Sarjana \& Pasca, 2020). In 2019 the most suspected measles cases in Central Java Province were in Sukoharjo (385 cases) (Dinas Kesehatan Provinsi Jawa Tengah, 2019).

Basic immunization is one of the services at the posyandu, a quick survey conducted in June showed that $75 \%$ of posyandu in Indonesia did not provide services due to the COVID-19 pandemic (Kemenkes RI, 2020). Including Sukoharjo, posyandu activities in every village have been cancelled since the outbreak of this pandemic. There are no more various health services such as providing additional food every month. This is part of efforts to prevent the spread of the COVID-19 pandemic. Information The coverage of basic immunization in Sukoharjo Regency during the COVID-19 pandemic according to the pocketbook for the first quarter of 2021, HB immunization coverage for 0-7 days in Central Java is $19.3 \%$ with a target of $23.7 \%$. In Sukoharjo, the achievement was $16.4 \%$, BCG immunization coverage in Central Java was $18.7 \%$ with a target of $23.7 \%$. In Sukoharjo, the achievement was $15.7 \%$, the DPT-HB-HIB 3 immunization coverage in Central Java was $18.2 \%$ with a target of $23.7 \%$. In Sukoharjo the achievement was $16.9 \%$, Polio 4 immunization coverage in Central Java was $17.8 \%$ with a target of $23.7 \%$. In Sukoharjo, the achievement was $16.9 \%$ Measles-Rubella immunization coverage in Central Java was $11.9 \%$ with a target of $23.75 \%$. In Sukoharjo, the achievement was $19.5 \%$. On the chart Sukoharjo is red (Harrington \& Gill, 1992).

Previous research has shown that the primary motivation for parents to immunize their babies is related to the desire to provide immediate benefits to the baby and concerns about the harmful transmission (Chandir et al., 2020). However, during this COVID-19 pandemic, parents are also worried about their child's transmission of COVID-19 if they meet with other people, and have to carry out basic immunizations at health service places due to the absence of Posyandu, such as having to go to clinics, hospitals, and so on.

Attitude is a factor that comes from within the mother. Attitude arises because of the stimulus or stimulation. The stimulus will give a response form of an attitude, which will manifest on action. However, a positive attitude does not necessarily translate into positive actions (Dwi Ghunayanti Novianda \& Mochammad Bagus, 2020). Utilization of Maternal and Child Health (MCH) books, MCH Handbooks contain information on maternal health (pregnancy, delivery and postpartum) and child health (monitoring growth and development, immunization and child health records) as well as various information on how to maintain and care for maternal and child health (Primary \& Care, 2017). By using the MCH handbook, mothers can be moved to live healthy life.

Therefore, the purpose of this study was to determine whether attitudes and use of the MCH handbook were related to the completeness of basic immunization during the COVID-19 pandemic in the Sukoharjo Region in 2021.

\section{Method}

The type of research is analytic observational, using quantitative research, a cross-sectional design using secondary data, is photos on basic immunization record sheets, and primary data in the form of answers to questionnaires by respondents who have children aged 0-20 months (research was conducted in October 2021, where COVID-19 was first reported in Indonesia in March 2020, therefore when the research was carried out, 
Indonesia had experienced a pandemic period of 19-20 months) and had an MCH handbook in the Sukoharjo Region.

The sampling technique used quota sampling with the results of 100 samples. Inclusion criteria were mothers who have children aged 0-20 months, have an $\mathrm{MCH}$ handbook, live in the Sukoharjo area, are not illiterate, and are willing to be research respondents. Data analysis was carried out univariate to present an overview of the distribution of all variables and bivariate analysis to see the relationship between variables the using chi-square test. The research ethics committee has approved this research of the Faculty of Medicine, University Airlangga (No. 189/EC/KEPK/FKUA/2021).

\section{Result}

This research was conducted in the Sukoharjo Region, Central Java, Indonesia. There were 100 samples of mothers who have children aged 0-20 months and have MCH books in 2021.

Table 1. Characteristics of Respondents Related to Basic Immunization

\begin{tabular}{|c|c|c|}
\hline Variable & $\mathrm{N}$ & $\%$ \\
\hline \multicolumn{3}{|l|}{ Education } \\
\hline Low & 45 & 45 \\
\hline High & 55 & 55 \\
\hline \multicolumn{3}{|l|}{ Knowledge } \\
\hline Not Enough & 32 & 32 \\
\hline Enough & 68 & 68 \\
\hline \multicolumn{3}{|l|}{ Attitude } \\
\hline Negative & 37 & 37 \\
\hline Positive & 63 & 63 \\
\hline \multicolumn{3}{|l|}{ Place Availability } \\
\hline Far & 18 & 18 \\
\hline Near & 82 & 82 \\
\hline \multicolumn{3}{|l|}{ Cost Availability } \\
\hline Expensive & 76 & 76 \\
\hline Cheap & 24 & 24 \\
\hline \multicolumn{3}{|l|}{ Time Availability } \\
\hline Not Available & 2 & 2 \\
\hline Available & 98 & 98 \\
\hline \multicolumn{3}{|l|}{ Husband Support } \\
\hline Doesn't Support & 12 & 12 \\
\hline Support & 88 & 88 \\
\hline \multicolumn{3}{|l|}{ Family Support } \\
\hline Doesn't Support & 13 & 13 \\
\hline Support & 87 & 87 \\
\hline
\end{tabular}




$\begin{array}{lcc}\text { Doesn't Support } & 51 & 51 \\ \text { Support } & 49 & 49 \\ \text { Health Cadre Support } & & \\ \text { Doesn't Support } & 34 & 34 \\ \text { Support } & 66 & 66 \\ \text { Utilization of MCH Books } & & \\ \text { Not Use } & 18 & 18 \\ \text { Use } & 82 & 82\end{array}$

Table 1 shows that more than half of the respondents have a high level of education. The majority have good knowledge. Most of the respondents have a positive attitude towards basic immunization during the COVID-19 pandemic, and the distance from their homes to immunization services is close. Basic immunization is expensive, only a small proportion of respondents do not take the time to provide basic immunizations for infants. And some respondents did not take advantage of the $\mathrm{MCH}$ handbook.

Table 1. The Relationship between Attitudes and Utilization of the MCH Handbook with Basic Immunization Completeness during the COVID-19 Pandemic in Sukoharjo in 2021.

\begin{tabular}{lccccc}
\hline Characteristics & \multicolumn{2}{c}{ Basic Immunization Completeness } & P-Value \\
& $\mathrm{N}$ & $\%$ & $\mathrm{~N}$ & $\%$ & \\
& & & & & 0,001 \\
& 20 & 54 & 17 & 46 & \\
\hline Attitude & 14 & 22,2 & 49 & 77,8 & \\
$\quad$ Negative & & & & & 0,000 \\
$\quad$ Positive & 13 & 72,2 & 5 & 27,8 & \\
Utilization of MCH Books & 21 & 25,6 & 61 & 74,4 & \\
$\quad$ Not Use & & & & & \\
$\quad$ Use & & & & & \\
\hline
\end{tabular}

Table 2 shows that from 37 respondents, about 20 respondents or $54 \%$ of respondents with negative attitudes had incomplete immunization status. There were 17 respondents or about $46 \%$ who had complete immunization status. Of the 63 respondents with a positive attitude, 14 respondents or about $22.2 \%$ had a positive attitude with incomplete immunization status, and 49 respondents or about $77.8 \%$ had complete immunization status. With the results of statistical tests obtained p-value $=0.001(\mathrm{p}<0.05)$, there is a significant relationship between positive or negative attitudes of respondents with the completeness of basic immunization in their babies.

In the utilization of the $\mathrm{MCH}$ book, 18 respondents, namely about 13 respondents or $72.2 \%$ of the respondents who did not use the $\mathrm{MCH}$ book, had incomplete immunization status. There were 5 respondents or around $27.8 \%$ who had complete immunization status. Of the 82 respondents who used the $\mathrm{MCH}$ handbook, 21 respondents or around $25.6 \%$ of the respondents used the MCH book, and 61 respondents or around $74.4 \%$ had complete immunization status. With the results of statistical tests obtained p-value $=0.000$ ( $\mathrm{p}<0.05$ ), there is a significant relationship between the use of MCH books by respondents and the completeness of basic immunization in infants. 


\section{Discussion}

From the results of research through primary and secondary data collection on mothers who have children aged 0-20 months and have an MCH book in October 2021 in Sukoharjo, there are 100 respondents. Respondents with a negative attitude majority had incomplete basic immunization status. In contrast, most respondents with a positive attitude had complete basic immunization status. With the results of statistical tests obtained $\mathrm{p}$-value $=0.001(\mathrm{p}<0.05)$ there is a significant relationship between positive or negative attitudes of respondents with the completeness of basic immunization in their babies. The results of this study are similar to the research conducted by (Putri \& Zuiatna, 2018) that mother's attitude towards immunization affects the mother's adherence to basic immunization for her child. Mothers with a good attitude level will follow immunization activities regularly.

A positive attitude can spread important information and the impact of not following immunization to the surrounding community, and a positive attitude has an important role in decision making. As research results (Dillyana, 2019) Mother's attitude towards immunization will impact the completeness of complete basic immunization for toddlers. And supported by research (Elise Putri, 2020) This is in accordance with Newcomb's theory which states that the better a person's attitude is, the more he can provide positive values, and is able to take responsibility for what he believes. Results of research (Katharina \& Iit, 2018). shows that the factors that influence attitudes, both external (experience, situation, norms, barriers and drivers) and internal (physiological, psychological and motives), affect the mother's attitude. Therefore, knowledge and information are needed to achieve a supportive attitude to the mother herself. If the mother's attitude is supportive, the mother will continuously monitor the growth and development of her child and realize the optimal growth and development of children according to their age. A positive mother's attitude can be a predisposing factor or trigger that causes mothers to bring their babies immunized (Arda et al., 2018).

Utilization of the MCH handbook, most respondents who did not use the $\mathrm{MCH}$ handbook had incomplete basic immunization status. On the other hand, the majority of respondents who used the $\mathrm{MCH}$ handbook had complete basic immunization status. With the results of statistical tests obtained p-value $=0.000(p<0.05)$, there is a significant relationship between the use of $\mathrm{MCH}$ books by respondents and the completeness of basic immunization in infants. Utilization of the $\mathrm{MCH}$ Handbook is an activity using processes and resources from the MCH Handbook to assist the learning process about health. This is in line with research (Kerja et al., 2019) regarding "The Relationship between the Use of MCH Handbooks and compliance with Complete Basic Immunization for Toddlers at the Sindang Barang Health Center, Bogor City in 2019", of 52 respondents, 31 (59.6\%) did not use $\mathrm{MCH}$ handbooks, and 21 (40.4\%) used $\mathrm{MCH}$ books. $\mathrm{MCH}$, with a value of $\mathrm{p}=0.000$, which means a significant relationship between the use of $\mathrm{MCH}$ books and Basic Immunization Completeness.

Utilization of MCH book information can be defined as the mother's actions in using $\mathrm{MCH}$ handbooks to seek information on children's health as well as administering basic immunizations to children according to the schedule on the immunization record sheet. By getting information from the $\mathrm{MCH}$ handbook, it is hoped that the mother's knowledge will increase about basic immunization. She can have a positive attitude with the importance of completeness of basic immunization.

This study still has several things that can be improved, namely researching with qualitative methods, so that the factors that affect the completeness of basic immunization can be studied more deeply, because currently this research is only using quantitative methods through online questionnaires, which the respondents may not answer according to the truth. And the design of this research is cross-sectional, where the measurement of the variables is done simultaneously. This research is the weakest research design for descriptive research. The relationship obtained only shows a relationship, not a causal relationship, so it can only analyze the relationship between the dependent and independent variables. 


\section{Conclusion}

The results of this study describe the relationship between the attitude factor and the use of MCH books by respondents with the completeness of basic infant immunization. From this study, it was found that if the respondent's attitude factor had a significant relationship with the completeness of basic immunization, where if the respondent was positive, the level of completeness of basic immunization was higher, and vice versa if the respondent was negative, the level of completeness of basic immunization was lower. Likewise, the use of the $\mathrm{MCH}$ handbook by the respondent has a significant relationship with the completeness status of the respondent's infant immunization, where if the respondent uses the $\mathrm{MCH}$ book, the level of completeness of basic immunization is higher, and vice versa if the respondent does not use the MCH book, the level of completeness of basic immunization is lower.

\section{Acknowledgements}

Acknowledgements to mothers in the Sukoharjo Region who participated in this research. Thank you to the Faculty of Medicine, University Airlangga for supporting this research.

\section{References}

Arda, Z. A., Hafid, W., \& Pulu, Z. (2018). Hubungan Pekerjaan, Sikap Dan Akses Dengan Kelengkapan Imunisasi Dasar Di Kabupaten Gorontalo. Health Care Media, 3(3), 12-16. https://stikeswch-malang.e-journal.id/Health/article/view/67

Chandir, S., Siddiqi, D. A., Mehmood, M., Setayesh, H., Siddique, M., Mirza, A., Soundardjee, R., Dharma, V. K., Shah, M. T., Abdullah, S., Akhter, M. A., Ali Khan, A., \& Khan, A. J. (2020). Impact of COVID-19 pandemic response on uptake of routine immunizations in Sindh, Pakistan: An analysis of provincial electronic immunization registry data. Vaccine, 38(45), 7146-7155. https://doi.org/10.1016/j.vaccine.2020.08.019

Dillyana, T. A. (2019). Hubungan Pengetahuan, Sikap Dan Persepsi Ibu Dengan Status Imunisasi Dasar Di Wonokusumo. Jurnal PROMKES, 7(1), 67. https://doi.org/10.20473/jpk.v7.i1.2019.67-77

Dinas Kesehatan Provinsi Jawa Tengah. (2019). Profil Kesehatan Provinsi Jateng Tahun 2019. Dinas Kesehatan Provinsi Jawa Tengah, 3511351(24), 273-275.

Dwi Ghunayanti Novianda, \& Mochammad Bagus, Q. (2020). Faktor yang Berhubungan dengan Perilaku Ibu dalam Pemenuhan Imunisasi Dasar. Journal of Health Science and Prevention, 4(2), 125-133. https://doi.org/10.29080/jhsp.v4i2.402

Elise Putri, C. E. (2020). Hubungan Pengetahuan Dengan Sikap Dalam Pemberian Imunisasi Dasar Lengkap Pada Ibu Yang Memiliki Bayi 0-9 Bulan Di Puskesmas Alianyang Tahun 2016. Jurnal_Kebidanan, 6(2), 125-133. https://doi.org/10.33486/jurnal_kebidanan.v6i2.49

Harrington, J. M., \& Gill, F. S. (1992). Buku Saku Kesehatan Kerja. Pocket Consultant, 3511351(24), 172-176.

Jayani, D. H. (2021). Pusat Kasus Covid-19 Indonesia Ada di Pulau Jawa. https://databoks.katadata.co.id/datapublish/2021/05/10/pusatkasus-covid-19-indonesia-ada-di-pulau-jawa-minggu-9-mei-2021

JOGJA, K. (2021). Akumulasi 5.906 Kasus, Gugus Tugas Pantau Data Corona Dampak Mudik Lebaran - KRJOGJA. https://www.krjogja.com/berita-lokal/jateng/solo/akumulasi-5-906-kasus-gugus-tugas-pantau-data-corona-dampak-mudiklebaran/

Katharina, T., \& Iit, K. (2018). Hubungan Antara Pengetahuan Ibu Dengan Sikap Terhadap Tumbuh Kembang Anak Usia 0-24 Bulan. Jurnal Kebidanan, 7(2), 134-141. https://doi.org/10.33486/jk.v7i2.28

Kemenkes RI. (2020). KEMENKES GELAR SHARING IMPLEMENTASI BUKU PEDOMAN KESEHATAN IBU DAN ANAK DI ERA PANDEMI. Kementerian Kesehatan RI., 1. https://www.kemkes.go.id/article/print/20111800006/kemenkes-gelar-sharingimplementasi-buku-pedoman-kesehatan-ibu-dan-anak-di-era-pandemi.html

Kementerian Kesehatan Republik Indonesia. (2020). Petunjuk Teknis Pelayanan Imunisasi Pada Masa Pandemi Covid-19. Covid-19 Kemenkes, 47. https://covid19.kemkes.go.id/protokol-covid-19/petunjuk-teknis-pelayanan-imunisasi-pada-masa-pandemi-covid19/\#.X6IYy6ozbIU

Kerja, W., Pasir, P., Bogor, M., \& Kunci, K. (2019). Jurnal Ilmiah Wijaya Volume 11 Nomor 2 , Juli - Desember 2019 Hal 166-182 ; website: www.jurnalwijaya.com; ISSN : 2301-4113 Jurnal Ilmiah Wijaya Volume 11 Nomor 2 , Juli - Desember 2019 Hal 166182 ; website : www.jurnalwijaya.com; ISSN : 2301-4113. 11(December 2018), 166-182.

Primary, T., \& Care, H. (2017). Optimalisasi peran kader dalam pemanfaatan buku kia di puskesmas tegalrejo kota yogyakarta. 0-7.

Privor-Dumm, L. A., Poland, G. A., Barratt, J., Durrheim, D. N., Deloria Knoll, M., Vasudevan, P., Jit, M., Bonvehí, P. E., \& Bonanni, P. 
(2020). A global agenda for older adult immunization in the COVID-19 era: A roadmap for action. Vaccine, xxxx. https://doi.org/10.1016/j.vaccine.2020.06.082

Putri, D. K., \& Zuiatna, D. (2018). Faktor Yang Mempengaruhi Perilaku Ibu terhadap Kelengkapan Imunisasi Dasar pada Bayi di Wilaya Kerja Puskesmas Satria Kota Tebing Tinggi. Jurnal Bidan Komunitas, 1(2), 104. https://doi.org/10.33085/jbk.v1i2.3977

Sarjana, P., \& Pasca, D. A. N. (2020). T a H U N 2020.1.

Scobie, H. M., Edelstein, M., Nicol, E., Morice, A., Rahimi, N., MacDonald, N. E., Carolina Danovaro-Holliday, M., \& Jawad, J. (2020). Improving the quality and use of immunization and surveillance data: Summary report of the Working Group of the Strategic Advisory Group of Experts on Immunization. Vaccine, 38(46), 7183-7197. https://doi.org/10.1016/j.vaccine.2020.09.017

Zhou, P., Yang, X. Lou, Wang, X. G., Hu, B., Zhang, L., Zhang, W., Si, H. R., Zhu, Y., Li, B., Huang, C. L., Chen, H. D., Chen, J., Luo, Y., Guo, H., Jiang, R. Di, Liu, M. Q., Chen, Y., Shen, X. R., Wang, X., ... Shi, Z. L. (2020). A pneumonia outbreak associated with a new coronavirus of probable bat origin. Nature, 579(7798), 270-273. https://doi.org/10.1038/s41586-020-2012-7 